price for their wood than that quoted for the pulp mill, a price that is still lower than the grower is at present getting, but within the range that he might he able to accept without putting himself out of business, provided every possible economy was made. Capital requirements would be about $£ 1-2$ million. In contrast with the prospects of further pulp mills, the most favourable area for board mills is considered to be southern England.

In the light of these surveys, it seems likely that Britain will have new wood-using mills of either or both types being built in the coming decade. There are not a few criticisms of the premises underlying these Sandwell reports with regard to costs, prices and trends, and suggestions that the size for profitability, at least for board mills, could be rather smaller and the capital cost less. However, it seems agreed that there must be a considerable reduction of the costs of growing and delivering the large amounts of wood required, and that there is certainly room for reduction by improved efficiency all along the line ; there will be every incentive for cheaper production as other markets are bound to fall during what, without such mills, will be a period of large over-production. In all cases there will be marketing problems, especially in view of the free competition of imports under the Outer Seven trade agreements, but cautious optimism appears justifiable, and expansion in the directions indicated is to be expected in the near future.

H. Champion

\title{
BIOCHEMISTRY AT THE IMPERIAL COLLEGE OF SCIENCE AND TECHNOLOGY, LONDON
}

T HE Imperial College of Science and Technology, London, has accepted a benefaction of $£ 350,000$ from the Isaac Wolfson Foundation to build and equip new laboratories for biochemistry and chemical microbiology and to support teaching and research in these subjects. Dr. E. B. Chain has been appointed to the chair of biochemistry and will take up the appointment in $\mathbf{1 9 6 1 .}$

This munificent benefaction will enable the College to erect a new building, to be known as the Wolfson Laboratory, adjacent to the Royal College of Science building in Imperial Institute Road. The Biochemistry Department will also occupy some laboratories in the Royal College of Science building shortly to be vacated by the Physics Department for its large new building in Prince Consort Road. Biochemistry at the College, which has been under the direction of a reader since the last occupant of the chair, Prof. A. C. Chibnall, succeeded Gowland Hopkins at Cambridge during the War, will thus burgeon out. The Department's new equipment will include fermentation units of comparatively large size and workshops for advanced mechanical and electronie equipment. It will provide accommodation for training and research in the neglected borderland between biochemistry and chemical engineering, and for research on an adequate scale on the biochemical production of chemicals of interest. Such a department, set in the Imperial College, with its very large school of engineering and flourishing schools of physics, organic chemistry and plant physiology, should find conditions highly propitious for major advances in biochemical knowledge.

Dr. Chain has since 1948 been at the Istituto Superiore di Sanità in Rome, where he has built up one of the best equipped, largest and most active centres of biochemical research in Europe. He has had there many of the facilities for which he had earlier, and unsuccessfully, pressed in Great Britainin particular, equipment of pilot-plant scale for fundamental studies of substances of microbial origin and biochemical interest.

Dr. Chain, a graduate of the University of Berlin, was forced to leave Germany by Nazi persecution in 1933 , and he became a British subject in 1939 . He first worked under Gowland Hopkins at Cambridge, on snake venoms and phospholipids. In 1935 came an invitation from Prof. (now Sir Howard) Florey to join the scientific staff of the Sir William Dunn School of Pathology at Oxford, with the object of organizing a biochemistry section there. As University lecturer in chemical pathology he remained at Oxford until the end of 1948. His work there included a study of the biochemical mode of action of some snake venoms, on the mode of action of lysozyme, on the mode of action of the spreading factor, on tumour metabolism and on a rapid method for the determination of phosphate. In 1938, with Florey, a systematic study of anti-bacterial substances produced by micro-organisms was started. This led to the discovery of the curative properties of penicillin and heralded the era of antibioties. In this work he played a leading part in the chemical studies on the isolation and structure of penicillin. For his part in the discovery of penicillin he was awarded the Nobel Prize for Medicine and Physiology in 1945, jointly with Sir Alexander Fleming and Florey. Dr. Chain was elected to fellowship of the Royal Society in 1949.

At the Istituto Superiore di Sanitì, with the support of Prof. D. Marotta, director of the Institute, and the Italian Government, Dr. Chain has carried out research in many directions. His collaborators have included chemical, mechanical and electronics engineers, biochemists, organic chemists, microbiologists and geneticists. A wide range of subjects has been studied, mainly in two fields of biochemistry, chemical microbiology and intermediate carbohydrate metabolism in animals, touching on the methodological, biochemical and biological as well as the chemical engineering aspects of the subjects.

Among the biochemical subjects studied in the field of chemical microbiology have been factors involved in the biosynthesis of penicillin. The continuation of this work led to the discovery, by a team of research workers in the Beecham Laboratories in England, to which Dr. Chain has acted as adviser and consultant, that the main part of the penicillin molecule (6-aminopenicillanic acid) could be made by biosynthesis, and that this could be modified afterwards by chemical means. A great range of new antibiotics can be made in this way. They include a penicillin which is acid-stable and can be taken by 
mouth and one which attacks staphylococci resistant to normal penicillin. Compounds of this kind open up exciting prospects in the antibiotics field.

Other studies conducted in Rome have been on the green iron-containing streptomycete pigment ferriverdin, on submerged kojic acid and citric acid fermentations and on the production of ergot alkaloid in submerged fermentation. Among the chemical engineering aspects of chemical microbiology there have been extensive studies on agitation and aeration. Biological studies have included investigations on the relations between morphology and metabolism in filamentous fungi and genetical problems in fila. mentous fungi. Studies on carbohydrate metabolism in animals have been concerned with the mode of action of insulin and the interrelations between carbohydrate and amino-acid metabolism in brain and nervous tissues.

\section{DIRECTION OF SCIENTIFIC AND TECHNICAL RESEARCH IN FRANCE}

\begin{abstract}
A
PUBLICATION, French Science News (2, April-June, 1959), published by the Direction Générale des Affaires Culturelles et Techniques for the Ministère des Affaires Étrangères, describes the organization which has been set up to determine policy for scientific and technical research throughout the country. Two high-ranking committees have been formed, the first being an Interministerial Committee, the members of which include the Prime Minister as chairman, the Minister of National Education, the Minister of the Armies, the Minister of Finance and Economic Affairs, the Minister of Industry and Commerce, the Minister of Agriculture, the Minister of Public Health, and qualified representatives of the French community.

The main tasks of the Interministerial Committee, which is responsible for proposing to the Government all measures for the development of scientific and technical research, are as follows :

"To maintain a fair balance between the amount of credits appropriated for the different fields of research ;

"To develop to its maximum usefulness French national research, which presupposes a detailed study of the profession of a research specialist and the milieu in which research is performed;

"To anticipate new research possibilities which will benefit the nation, which presupposes long-
\end{abstract}

term government options in the field of science."

The second is an Advisory Committee, the members of which are: Maurice Letort as chairman (Letort is scientific director of Research and Studies, Centre of Charbonnages de France); Prof. Pierre Aigrain. vice-president of the Paris Faculty of Science; Prof. Jean Bernard, Paris Faculty of Medicine; Prof. Rene Dumont, National Agronomic Institute; Prof. Paul Germain, Paris Faculty of Science; Rene Latarjet, co-director of the Radium Institute and the Curie Foundation; Prof. Andre Lichnerowicz, Collège de France; Maurice Ponte, general director of the Compagnie Générale de T.S.F.; Prof. Charles Sadron, Strasbourg Faculty of Science and director of the Centre of Macromolecular Research; Pierre Taranger, industrial director of the French Atomic Energy Commission; and Felix Trombe, research director at the National Scientific Research Centre (Mont-Louis).

The Committees are served by a common secretariat directed by a general delegate. The general delegate can form work committees for specific objects and composed of experts. He works in close co-operation with the general planning commissioner.

The journal is published quarterly by the Association pour la Diffusion de la Pensée Francaise, 23, rue La Perouse, Paris, $16^{\mathrm{e}}$.

\section{PRODUCTION AND CONSUMPTION OF ENERGY IN GREAT BRITAIN}

\begin{abstract}
$\mathrm{D}^{2}$ URING the past four years some remarkable changes have taken place in the consumption of energy in the United Kingdom. Indeed, since the War the situation in the whole of Western Europe has changed, from that of an energy-exporting economy to that of an energy-importing one. A few years ago there were fears of a shortage of energy in Great Britain. To-day there is the picture of rapidly rising coal stocks, and of real alarm in the mining villages.

Recently this subject was dealt with in an enlightening talk to the Fuel Luncheon Club by Sir Harold Hartley*, whose association with the international study of the energy problems of Western Europe entitle him to be listened to with earnest attention.

* Talk to the Fuel Luncheon Club on January 19 on "Energy in * Talk to the Fuel Luncheon Club on January 19 on "Energy in
the United Kingdon-the Changing Scene", by Sir Harold Hartley.
\end{abstract}

His revelations should disturb any complacency with regard to the extent of our technological effort in the development of our coal resources.

The pattern of the energy consumption has changed quickly in the following respects in the past four years. Coal consumption fell 3 per cent per annum between 1955 and 1959 , while that of oil rose by 12 per cent per annum. Electrieity consumption continued its steady annual rise of 6 per cent, while gas declined by 1 per cent per annum. The competitive position depends upon factors of efficiency and of convenience, the relative basic prices of the therm in the primary forms of energy being : coal at the pithead, price $3 \frac{1}{2} d$., at $£ 10$ per ton, $8 \frac{1}{2} d$.; fuel oil, at $£ 10$ per ton, $6 d$.; paraffin, at $£ 20$ per ton. $11 d$.; while gas at the average price costs $1 s .9 d$. per therm, and electricity at $1 \cdot 55 d$. per unit, $3 s .9 d$. 